\title{
Why the Ohio Early Voting Case Is Not a Threat to Military Voting Accommodations
}

\author{
STEVEN F. HUEFNER* \\ TABLE OF CONTENTS
}

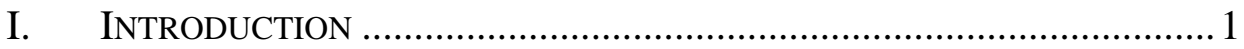

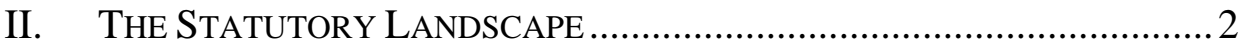

III. THE FEDERAL COURTS GRANT RELIEF ............................................ 6

IV. IMPACT ON OTHER MilitARY VOTING ACCOMMODATIONS ..............8

V. CONCLUSION.................................................................... 12

\section{INTRODUCTION}

One of the most closely watched court battles of the 2012 presidential election was the lawsuit that the Obama campaign brought against the Ohio secretary of state in an attempt to restore early in-person voting for all Ohio voters on the final three days before Election Day. The case-Obama for America $v$. Husted ${ }^{1}$ —revolved around the simple fact that in the 2012 election, new Ohio laws permitted county boards of elections to offer early in-person voting only to military voters on these final three days, but halted early voting for all other voters at 6:00 p.m. on the Friday before Election Day. Because in the 2008 presidential election some 100,000 non-military Ohio voters had voted during the same final three days of early voting, and because the Obama campaign and its co-plaintiffs, the Democratic National Committee and the Ohio Democratic Party, saw these voters as tending to vote Democratic, the lawsuit was seen as potentially critical to the outcome of a close Ohio race.

The equal protection claim at the core of the Obama for America suit was initially greeted with skepticism by many knowledgeable observers, who presumed that the state was free to provide these additional early voting hours, like many other accommodations, exclusively to military voters. ${ }^{2}$ These prognosticators were surprised when the federal district court issued a preliminary injunction, later affirmed by the Sixth Circuit, requiring Ohio to offer all other voters the same early voting opportunities that it provided to

* Professor of Law and Senior Fellow of Election Law @ Moritz, The Ohio State University Michael E. Moritz College of Law. I am grateful for the advice and encouragement of my Election Law @ Moritz colleagues Terri Enns and Ned Foley.

1697 F.3d 423, 423 (6th Cir. 2012).

2 See, e.g., Edward B. Foley, Analyzing a "Voting Wars" Trifecta, Free \& Fair Blog, ELECTION LAw @ MORITZ (Aug. 16, 2012), http://moritzlaw.osu.edu/electionlaw/ freefair/index.php?ID=9579 (predicting the argument would fail); Richard L. Hasen, Is the Supreme Court About to Swing Another Presidential Election?, SLATE (Oct. 15, 2012, 3:52 PM), http://www.slate.com/articles/news_and_politics/politics/2012/10/if_the_supreme_ court_cuts_early_voting_in_ohio_it_could_swing_the_state.html (calling the plaintiffs' claim “a major stretch”). 
military voters. ${ }^{3}$ The secretary of state then set uniform hours allowing all Ohio voters the opportunity of early in-person voting on the final Saturday, Sunday, and Monday, ${ }^{4}$ and the rest is history.

But what about the long-term legal impact of the case? A number of military organizations took an active interest in the proceedings, mostly in opposition to the plaintiffs, whether as intervenors, amici curiae, or commentators. The core of their interest was a concern that the case was a threat to all assistance for military voters. For instance, in their brief to the Sixth Circuit, the Intervenors wrote that the suit could mean that "state and local governments soon will stop offering such assistance, and the fundamental right to vote of the members of our Armed Forces will be undermined." 5

Fortunately, this is a highly unlikely result. Indeed, as discussed below, the case provides very little reason to worry about the constitutionality of other military voting accommodations, notwithstanding the Intervenors' strong opposition to the outcome in this case. Part II first provides the necessary underpinnings of the issues raised in the litigation. Parts III and IV then turn to an analysis of the judicial decisions, and to the impact on military voting generally of the way in which the federal courts resolved the case.

\section{THE STATUTORY LANDSCAPE}

Military voters benefit from a variety of federal and state assistance to help them overcome their unique voting challenges. Since 1986, the Uniformed and Overseas Citizens Absentee Voting Act (UOCAVA) has guaranteed overseas voters and active duty military who are absent from their voting residence a right to participate in federal elections conducted in their home state, and also has required states to follow certain processes to facilitate the exercise of that right. ${ }^{6}$ To improve these processes, in 2009 Congress passed the Military and Overseas Voter Empowerment (MOVE) $\mathrm{Act}^{7}$ as an amendment to the UOCAVA. Among other provisions, the MOVE Act requires that states transmit absentee ballots no later than forty-five days before Election Day to qualified UOCAVA voters who have applied for them, and that they transmit the ballots electronically to voters who request this mode of transmission. ${ }^{8}$

\footnotetext{
${ }^{3}$ Obama for Am., 697 F.3d at 425.

${ }^{4}$ See Directive No. 2012-50 from John Husted, Ohio Sec’y of State, to All Cnty. Bds. of Election (Oct. 16, 2012), available at http://www.sos.state.oh.us/SOS/Upload/elections/ directives/2012/Dir2012-50.pdf.

${ }^{5}$ Brief of Intervenor Defendants-Appellants Military Groups at 3, Obama for Am. v. Husted, 697 F.3d 423 (6th Cir. 2012) (No. 12-4076), available at http://moritzlaw.osu.edu/ electionlaw/litigation/documents/BriefofIntervenorMilitaryGroups.pdf.

642 U.S.C. §§ $1973 f f$ to $1973 f f-7$ (Supp. IV 2011).

${ }^{7}$ Military and Overseas Voter Empowerment Act, Pub. L. No. 111-84, §§ 575-89, 123 Stat. 2318-35 (2009).

${ }^{8}$ Id. at $\S \S 578(f)(1), 579(\mathrm{a})(8)(\mathrm{A})$.
} 
In 2010, the Uniform Law Commission (formally titled the National Conference of Commissioners on Uniform State Laws) completed a two-year drafting process that led to its promulgation of a new uniform state law, recommended for enactment in all fifty states. This law, called the Uniform Military and Overseas Voters Act (UMOVA), ${ }^{9}$ not only offered a template for states to use in complying with the MOVE Act, but also extended coverage to a broader category of overseas voters, as well as to active duty military whether or not they are absent from their voting residence. In many other ways as well, UMOVA continued to improve the voting opportunities available to military and overseas voters. ${ }^{10}$

From 2005 through 2010, Ohio law allowed early in-person voting to begin thirty-five days before Election Day, and to continue through the Monday immediately prior to Election Day, if county boards of elections desired. ${ }^{11}$ In June 2011, as part of a package of election law reforms in House Bill (H.B.) 194, the Ohio General Assembly reduced the period of early in-person voting. The measure was bitterly opposed by many Democrats, but supporters of the measure argued that five weeks of early voting were excessive, and that having to conduct early voting on the last three days before Election Day unduly interfered with local election officials' final preparations. Accordingly, H.B. 194 amended state law to begin the period of early in-person voting three weeks before Election Day, and to end it on the Friday before Election Day. Specifically, H.B. 194 set 6:00 p.m. that Friday as the endpoint for all voters, and did so by amending two separate statutory sections, one (Ohio Revised Code (O.R.C.) § 3509.01) applicable to regular voters, and another (O.R.C. $\S 3511.10$ ) applicable to military and overseas voters. ${ }^{12}$

The saga of Ohio's 2012 early in-person voting hours was just beginning, however. The legislature had overlooked two other existing statutory provisions - one (O.R.C. § 3509.03) applicable to regular voters, and the other (O.R.C. § 3511.02) applicable to military and overseas voters-that each specified that early in-person voting continued until the close of business the

\footnotetext{
${ }^{9}$ See UnIfORM Military AND OVERSEAS VOTERS ACT (2010), available at http://www.uniformlaws.org/shared/docs/military\%20and\%20overseas\%20voters/umova_fi nal_10.pdf.

${ }^{10}$ I served as the Reporter to the Uniform Law Commission drafting committee that prepared UMOVA, and my work in that role informs my understanding of the obstacles facing military and overseas voters, and of the impact of the set of federal and state accommodations created for these voters.

${ }^{11}$ See OHIO ReV. CoDE ANN. §§ 3509.01(B)(2), 3509.03(I) (West Supp. 2012). In the 2008 presidential election, many voters took advantage of the first five days of early voting as an opportunity to register and vote simultaneously, because Ohio law permits voters to register until thirty days before an election. Meanwhile, close to 105,000 voters took advantage of the final three days of early voting that year. See Obama for Am. v. Husted, 697 F.3d 423, 426 (6th Cir. 2012).

12 See Amended Substitute H.B. 194, 129th Gen. Assemb., sec. 1, §§ 3509.01, 3511.10 (Ohio 2011), available at http://www.legislature.state.oh.us/BillText129/129_HB_194_EN_ N.html.
} 
Monday before Election Day. ${ }^{13}$ To remedy the inconsistency between these provisions and H.B. 194, the legislature quickly passed a separate "technical corrections" measure to amend these provisions, changing their specification of the end of early voting to the previous Friday at 6:00 p.m., instead of close-ofbusiness Monday. These corrections were passed as part of H.B. 224, a bipartisan bill that passed unanimously as an emergency law, whose main provisions provided other accommodations for military and overseas voters. ${ }^{14}$ As an "emergency law," H.B. 224 was not subject to the possibility of a public referendum.

At this point, the law was clear: no voters, military or non-military, could vote early in-person after 6:00 p.m. on the Friday before Election Day. But the law continued to evolve. Before any of the provisions of H.B. 194 had taken effect, opponents quickly collected enough signatures to delay its implementation until Ohio voters could approve or disapprove it by referendum at the next general election, slated for November 2012.15 The referendum pertained only to H.B. 194, and therefore delayed only its provisions, but not the "technical corrections" of H.B. 224, which had been intended to harmonize all the early voting sections of the Ohio code. ${ }^{16}$

The result was an unintended mess. With respect to military and overseas voters, one pre-existing provision, which H.B. 194 would have changed but which now remained in effect, allowed early in-person voting through Election Day. ${ }^{17}$ But the technical correction of H.B. 224 called for early in-person voting to end at 6:00 p.m. on the Friday before, a clear statutory conflict. ${ }^{18}$ As for all other voters, the other technical correction of H.B. 224 also called for early inperson voting to end at 6:00 p.m. Friday. ${ }^{19}$ Meanwhile, the pre-existing provision that H.B. 194 also would have amended to add the same 6:00 p.m. Friday deadline did not say anything about the endpoint of early in-person voting for all other voters, and instead provided only that early voting would

13 See OHIo Rev. CodE AnN. §§ 3509.03, 3511.02 (West Supp. 2012).

14 See Amended Substitute H.B. 224, 129th Gen. Assemb., sec. 1, §§ 3509.03, 3511.02 (Ohio 2011), available at http://www.legislature.state.oh.us/BillText129/129_HB_ 224_EN_N.html.

15 See Joe Hallett, HB 194 Foes Turn in Signatures, Columbus Dispatch, Sept. 30, 2011, http:/www.dispatch.com/content/stories/local/2011/09/30/hb-194-foes-turn-insignatures.html\#comment; Secretary of State Husted Certifies HB 194 Referendum Petition Signatures, OHIO SECRETARY OF STATE (Dec. 9, 2011), http://www.sos.state.oh.us/ mediaCenter/2011/2011-12-09.aspx.

16 Secretary of State Husted Certifies HB 194 Referendum Petition Signatures, ОніО SECRETARY OF STATE (Dec. 9, 2011), http://www.sos.state.oh.us/mediaCenter/2011/201112-09.aspx.

${ }^{17}$ See Amended Substitute H.B. 194, 129th Gen. Assemb., sec. 1, § 3511.10 (Ohio 2011), available at http://www.legislature.state.oh.us/BillText129/129_HB_194_EN_ N.html.

18 See supra note 14 , at sec. 1 , § 3511.02 .

19 See supra note 14 , at sec. 1 , § 3509.03. 
begin thirty-five days before Election Day. ${ }^{20}$ Thus, no statutory conflict existed concerning the extent of early in-person voting opportunities for regular voters. But the provisions for regular voters no longer matched those for military voters, despite the legislature's efforts to treat military and non-military voters alike for purposes of early in-person voting.

In October 2011, Ohio Secretary of State John Husted prepared an Advisory to resolve the clear statutory conflict over the early voting deadline for military voters. ${ }^{21}$ In preparing this Advisory, the secretary of state could have looked to the General Provisions of the Ohio Revised Code for some guidance: O.R.C. $\S 1.52$ provides that where two statutory provisions conflict, the provision "latest in date...prevails," a reformulation of the familiar canon of interpretation that a more recently enacted statute controls an earlier enacted statute. $^{22}$ Here, the latest enactment was H.B. 224, which provided the new deadline of Friday at 6:00 p.m. Imposing this deadline for military voters also would have been consistent with the legislature's efforts to establish identical early voting opportunities for all voters.

However, the secretary of state's Advisory instead picked the older deadline, erring on the side of accommodating military voters as expansively as possible. ${ }^{23}$ The Advisory ordered Ohio county boards of elections to continue to follow the pre-2011 law that permitted early in-person voting by military voters through Election Day, ${ }^{24}$ notwithstanding the new Friday deadline of the technical correction in H.B. 224. This Advisory set the essential legal landscape on which the Obama campaign built its July 2012 equal protection claim. ${ }^{25}$

20 See OHIo Rev. Code AnN. § 3509.01 (West Supp. 2012).

${ }^{21}$ Advisory No. 2011-07 from John Husted, Ohio Sec’y of State, to All Cnty Bds. of Election 2 (Oct. 14, 2011), available at http://www.sos.state.oh.us/SOS/Upload/elections/ advisories/2011/Adv2011-07.pdf.

22 OHIO REV. CoDE ANN. § 1.52 (West Supp. 2012).

23 Husted, supra note 21, at 2.

${ }^{24}$ Id. However, until the enactment of other provisions in H.B. 224, Ohio law matched federal law (UOCAVA) in requiring a military voter to be "absent” because of military duty in order to take advantage of Ohio's accommodations for military voters. An absent military voter would not generally be able to take advantage of early in-person voting. H.B. 224 changed this to follow UMOVA in permitting any active duty military, whether absent or not, to use Ohio's military voter accommodations. See Amended Substitute H.B. 224, 129th Gen. Assemb., sec. 1, $\S \S 3509.10$, 3511.01(C) (Ohio 2012), available at http:// www.legislature.state.oh.us/BillText129/129_HB_224_EN_N.html; infra text accompanying notes 57-59.

${ }^{25}$ In May 2012, the Ohio General Assembly repealed H.B. 194 in its entirety, thereby nullifying the upcoming referendum concerning H.B. 194. In their brief, the intervenors used this legislative action to argue that now the statute "latest in date" was this repealer, which reestablished for military voters the deadline existing before H.B. 194 was enacted. See Brief of Intervenor Defendants-Appellants Military Groups at 15-16, Obama for Am. v. Husted, 697 F.3d 423 (6th Cir. 2012) (No. 12-4076), available at http://moritzlaw.osu.edu/ electionlaw/litigation/documents/BriefofIntervenorMilitaryGroups.pdf. This argument elided the facts that the operative Directive was issued long before this repeal, that, at the time of this repeal, the pre-existing deadline was already the operative deadline because H.B. 194 


\section{THE FEDERAL COURTS GRANT RELIEF}

As Part II has summarized, both the nature of Ohio's additional early inperson voting opportunities for UOCAVA voters, and the way in which these voters received this favorable treatment, were somewhat peculiar. This peculiar background had a substantial influence on the federal courts' disposition of the Obama campaign's lawsuit. In granting a preliminary injunction to restore early in-person voting for all Ohio voters, both the district court and the Sixth Circuit were heavily influenced by their conclusion that Ohio's reduced early voting period placed a new burden on non-military voters, and by their conclusion that the state lacked a sufficiently weighty interest to justify this differential treatment.

On August 31, 2012, the United States District Court for the Southern District of Ohio issued an opinion and order enjoining Ohio from enforcing the provisions of H.B. 224, as construed by the secretary of state, that halted early in-person voting at 6:00 p.m. on the Friday before Election Day for all but military voters. ${ }^{26}$ The district court began its opinion with this characterization: "In 2005, Ohio expanded participation in absentee balloting and in-person early voting to include all registered Ohio voters. Now, 'in-person early voting' has been redefined by the Ohio legislature to limit Plaintiffs' access to the polls."27 This perspective shaped the district court's view that for purposes of this equal protection claim, Ohio needed more than the traditional rational basis to justify discriminating among different categories of voters. Instead, the court employed the legal standard developed in the Anderson v. Celebrezze ${ }^{28}$ and Burdick v. Takushi $^{29}$ cases for when the right to vote is burdened, under which the distinction "must be justified by ... state interests sufficiently weighty to justify the limitation." 30 Upon review, the Sixth Circuit embraced the same legal standard. ${ }^{31}$

On the facts before it, which included four uncontested studies presented by the plaintiffs, the district court concluded that eliminating early in-person voting on the final three days for all but military voters would burden many thousands

had never taken effect, and that a metaphysical issue therefore existed of whether there even was anything to repeal during the period after the referendum petition for H.B. 194 was qualified but before the public had resolved, by the referendum, the issue of whether H.B. 194 should become law. Meanwhile, the plaintiffs attempted to suggest that it was this repeal, motivated primarily by a political desire to take the wind out the sails of the referendum, that gave rise to the statutory conflict, when in fact the statutory conflict arose as soon as the referendum process nullified the effective date of H.B. 194.

26 Obama for Am. v. Husted, No. 2:12-CV-0636, 2012 WL 3765060, at*11 (S.D. Ohio Aug. 31, 2012), aff'd, 697 F.3d 423, 437 (6th Cir. 2012).

27 Obama for Am., 2012 WL 3765060, at *1.

28460 U.S. 780, 788-89 (1983).

29504 U.S. 428, 434 (1992).

30 Obama for Am., 2012 WL 3765060, at *6 (quoting Crawford v. Marion Cnty. Election Bd., 553 U.S. 181, 191 (2008)).

${ }^{31}$ Obama for Am., 697 F.3d at 431. 
of Ohio voters, including minority and working-class voters who in 2008 had been the heaviest users of the final weekend of early voting. ${ }^{32}$ The Sixth Circuit not only embraced this conclusion, but also added that the district court record included evidence that "a significant number of Ohio voters will in fact be precluded from voting without the additional three days." 33 It clarified that it did not mean that these voters would be legally precluded or prohibited from voting, but only that they would in fact otherwise fail to find "alternate means of access to the ballot." 34

The district court then considered whether Ohio's two proffered reasons for the differential treatment were sufficiently weighty. One reason was the desire to protect election boards and allow them to focus all their attention on Election Day preparation during the final three days, instead of also having to conduct early in-person voting. The court found "insufficient evidence" that election boards could not simultaneously do both, noting that it had before it conflicting representations on this point from state and county election officials. ${ }^{35}$ In affirming the district court, the Sixth Circuit also noted that for six years Ohio election officials had successfully conducted elections with early in-person voting on the final three days. ${ }^{36}$

Ohio's second reason was that military voters are often subject to sudden deployment on a moment's notice. The defendants argued to the court that without the option of early in-person voting on the final three days, some of these military voters would be unable to vote. But the court observed that the Ohio statutory framework did not in fact ensure that these very military voters would be able to vote, because each county retained the discretion to decide whether or not to open its election offices for military voters on the final weekend. Moreover, the record before the court suggested that most Ohio county election offices actually would not be open. Thus, although the court had agreed that this proffered justification "[a]t first glance... appears to weigh heavily in favor of Defendants," 37 in the end the court found the interest "not ... strong" because the state itself had not even secured this interest except

32 Obama for Am., 2012 WL 3765060, at *3-4, *7.

33 Obama for Am., 697 F.3d at 431.

${ }^{34}$ Id. (quoting Citizens for Legislative Choice v. Miller, 144 F.3d 916, 921 (6th Cir. 1998)). Judge White, concurring with the majority in affirming the district court, rejected the majority's conclusion that the elimination of the last three days of early voting would preclude "a significant number of Ohio voters" from voting. Id. at 440. Nonetheless, she concluded that the resulting burden on some voters was substantial, and could not be divorced from what she described as "eleventh-hour changes" to voting rules in place since 2005, intended to remedy the burden of long lines at the polls. Id. at 442 . Further concluding that the defendants' asserted concern about abrupt military deployments "had no relation to the statutory distinction" between military and non-military voters, Judge White also found the Anderson-Burdick balancing to favor the plaintiffs. Id. at 443.

35 Obama for Am., 2012 WL 3765060, at *8.

36 Obama for Am., 697 F.3d at 433.

37 Obama for Am., 2012 WL 3765060, at *8. 
on the final Monday. ${ }^{38}$ The Sixth Circuit similarly called the state's proffered interest "a worthy and commendable goal," but found "no corresponding satisfactory reason to prevent non-military voters from casting their ballots as well." 39

By its terms, the district court's preliminary injunction appeared to require that Ohio make early in-person voting available to all voters on the last three days before Election Day. ${ }^{40}$ This would be sweeping relief, given that the district court's own analysis depended in substantial part on the fact that county boards of election could decide for themselves whether to even provide military voters with this opportunity, and most Ohio counties apparently were not likely to do so. The district court's decision in this regard appeared to rely on the secretary of state's avowed desire, expressed in another context, to make early voting hours uniform throughout the state. ${ }^{41}$ However, in affirming the district court's conclusion that Ohio had violated the Equal Protection Clause, the Sixth Circuit construed the preliminary injunction to require only that Ohio return to the status quo ante, as it existed before H.B. 194 and H.B. $224 .{ }^{42}$ That would leave Ohio counties with the discretion to decide whether to make early voting available, provided that whatever early voting counties offered was open to all voters to the same extent that it was available to the military. However, the secretary of state, assuredly because he had already shown his commitment to uniform early voting schedules around the state, then set uniform statewide hours for early in-person voting on the final three days for all voters. ${ }^{43}$

\section{IMPACT ON OTHER MILITARY VOTING ACCOMMODATIONS}

The Sixth Circuit's affirmance of the preliminary injunction essentially settled the impact of Obama for America on the November 2012 election. ${ }^{4}$ Because of the injunction, Ohio provided early in-person voting to all Ohio voters on the final Saturday, Sunday, and Monday of the 2012 election. But as of this writing, the issue of whether to grant permanent injunctive relief against enforcing H.B. 224 remains pending before the district court. Questions about

38 Id. at $* 9$.

39 Obama for Am., 697 F.3d at 434.

40 Obama for Am., 2012 WL 3765060, at *11.

${ }^{41}$ Directive No. 2012-35 from John Husted, Ohio Sec'y of State, to All Cnty. Bds. of Election 1 (Aug. 15, 2012), available at http://www.sos.state.oh.us/SOS/Upload/ elections/directives/2012/Dir2012-35.pdf; see also Obama for Am., 2012 WL 3765060, at *3.

42 Obama for Am., 697 F.3d at 437.

43 See Directive No. 2012-50 from John Husted, Ohio Sec’y of State, to All Cnty. Bds. of Election (Oct. 16, 2012), available at http://www.sos.state.oh.us/SOS/Upload/elections/ directives/2012/Dir2012-50.pdf.

44 The Supreme Court denied an application for a stay of the preliminary injunction on Oct. 16, 2012. Husted v. Obama for Am., 133 S. Ct. 497 (2012). 
the extent to which the equal protection claim might jeopardize other areas of military voting are sure to be part of the argument before the court.

Of course, if the defendants ultimately convince the court that Ohio's distinction in early in-person voting opportunities for military and non-military personnel does not violate the Equal Protection Clause, then the August 2012 grant of the preliminary injunction will become a complete non-event for purposes of any precedential impact on other military voting accommodations. Indeed, substantial arguments remain that Ohio should have been able to limit the final three days of early voting only to military voters. But the discussion below argues that even if the plaintiffs ultimately do succeed on the merits of their equal protection claim - as the courts at the preliminary injunction stage have already said is "likely" - that result will do little to alter the long-settled principle that state legislatures and Congress generally may provide military voters a host of special accommodations without violating the Equal Protection Clause. ${ }^{45}$ Neither the various accommodations already provided to military voters, nor future new accommodations, seem seriously at risk.

In part, this is because the courts themselves are so clearly committed to preserving accommodations for military voters. For instance, in granting the preliminary injunction, both the district court and the circuit court were careful to note that the injunction would in no way reduce the voting opportunities available to Ohio military voters in the 2012 election. ${ }^{46}$ Furthermore, both courts were at pains to explain their equal protection analysis in terms that would continue to sustain typical military voting accommodations, because of both the substantial state justifications for these accommodations and the minor burdens they imposed on other voters, as balanced under the Anderson-Burdick test. ${ }^{47}$ Albeit in dicta, the courts accordingly expressed continuing support for the full range of accommodations for military and overseas voters enacted in statutes such as the UOCAVA, the MOVE Act, and various state statutes. ${ }^{48}$

In addition to the courts' desire to protect military voting accommodations, these accommodations also likely remain safe because most of them can be easily justified under existing doctrine. As the Sixth Circuit noted, typical

45 See Romeu v. Cohen, 265 F.3d 118, 124 (2d Cir. 2001); see also McDonald v. Bd. of Election Comm'rs, 394 U.S. 802, 809-11 (1969) (holding generally that limiting absentee voting provisions only to certain classes of voters does not violate Equal Protection Clause).

46 See Obama for Am., 697 F.3d at 434-35; Obama for Am., 2012 WL 3765060, at *10. Of course, another concern is that requiring the state to allow all voters to participate equally in a voting opportunity initially granted only to military voters could lead a state to entirely eliminate that opportunity, whether as a cost-saving or burden-reducing measure, or as a partisan calculation, to the detriment of the military voters who would have benefitted if the state could offer the opportunity only to them. The courts were sensitive to this, and reasonably concluded that Ohio's decision here was not truly driven by either cost or burden. See id. at 435-36.

10.

47 See Obama for Am., 697 F.3d at 434-35; Obama for Am., 2012 WL 3765060, at *8-

48 See Obama for Am, 697 F.3d at 434-35; Obama for Am., 2012 WL 3765060, at *910. 
military voting accommodations "are based on highly relevant distinctions between [military voters] and the civilian population, and they confer benefits accordingly."49 Implicit in this comment was a sense that the distinction between military and non-military voters was less relevant with respect to early in-person voting. Indeed, the circuit court noted that the problems facing military voters overwhelmingly involve mail delays and communication difficulties, problems that additional in-person voting opportunities do not remedy, in contrast with the bulk of military voting accommodations. ${ }^{50}$

An intriguing dimension of this distinction is that the accommodations most responsive to the typical voting obstacles facing military voters involve the absentee voting process, while the accommodation at issue in the Obama for America case involved in-person voting. As Richard Pildes has suggested, inperson early voting is perhaps best understood as an expansion of Election Day voting, not as a type of absentee voting. ${ }^{51}$ Arguably, in the same way that differential opportunities to access the polls on Election Day would trench upon the fundamental right to vote, differential opportunities for early in-person voting raise greater constitutional issues than do measures for no-excuse absentee voting, for which there is no fundamental constitutional right. ${ }^{52}$ The plaintiffs in the Obama for America case themselves had argued that the many equal protection precedents upholding variations in absentee voting options available to different kinds of voters were inapplicable, in that none of them "directly restricted access to the ballot box." 53

Yet even if a distinction between early in-person voting and absentee voting ultimately proves chimerical as a matter of legal doctrine, it remains true that the difference in relative need for early in-person voting between military and non-military voters was much smaller than the differences in need for other voting accommodations. In its complaint, Obama for America had claimed that in fact there was no relevant difference, because military and non-military voters were "identically situated" with respect to early in-person voting. ${ }^{54}$ The defendants were quick to counter that military voters were not identically situated, because of the prospect of a sudden deployment right before Election Day. But the courts saw this difficulty as not nearly as different, either in

${ }^{49}$ Obama for Am, 697 F.3d at 434.

50 See id.

${ }^{51}$ Richard Pildes, Early Voting and Constitutional Law, ElECTION LAW BLOG (Nov. 27, 2012, 4:25 PM), http://electionlawblog.org/?author=7.

52 See McDonald v. Bd. of Election Comm'rs, 394 U.S. 802, 807-08 (1969).

53 See Plaintiffs' Memorandum of Law in Further Support of Plaintiffs' Motion for a Preliminary Injunction and in Opposition to Intervenors' Motion to Dismiss at 8, Obama for Am. v. Husted, No. 2:12-CV-0636, 2012 WL 3765060 (S.D. Ohio Aug. 31, 2012), available at

http://moritzlaw.osu.edu/electionlaw/litigation/documents/PlaintiffsMemorandumofLawinFu rtherSupportofPlaintiffsMotionforaPreliminaryInjunction.pdf.

${ }^{54}$ Complaint at 3, Obama for Am. v. Husted, No. 2:12-CV-0636, 2012 WL 3765060 (S.D. Ohio Aug. 31, 2012), available at http://moritzlaw.osu.edu/electionlaw/litigation/ documents/ObamaforAmericavHustedcomplaint.pdf. 
quality or degree, from comparable difficulties non-military voters also may face when required, whether for work or personal reasons, to travel away from home at the last minute just before Election Day.

To be sure, non-military voters whose voting opportunities may be burdened by abrupt travel requirements are not risking their lives to defend their country under an organization in which the government exercises tight control over their personal affairs. ${ }^{55}$ But Ohio had not even guaranteed that its early voting scheme would solve this problem for military voters. The courts also concluded that if Ohio did provide early voting for some voters, it could provide it for all voters without a substantial additional state burden.

Indeed, in assessing the comparative value of early in-person voting to different categories of voters, it is worth reflecting for a moment whether the prototypical military voter would even be able to take advantage of early inperson voting. The UOCAVA and most state laws have defined the type of military voter to whom their protections apply as a voter who is "absent" from the voter's place of voting residence. ${ }^{56}$ At the least, difficult interpretive questions therefore would arise about whether a military voter seeking to vote in-person is even covered by these statutes. The UMOVA, in contrast, redefined military voters to include all active duty military personnel, whether or not "absent" from their home precincts, precisely to provide a means of accommodating abrupt military deployments. ${ }^{57}$ Ohio, in a separate portion of H.B. 224, enacted selected parts of UMOVA, including this broader category of covered military voters. ${ }^{58}$ Under this broadened definition, any military voter is proactively able to use the military voting process, allowing the voter to register and apply for an absentee ballot simultaneously, to receive the ballot electronically at least forty-five days before Election Day, and even to use a Federal Write-in Absentee Ballot (FWAB) as a simultaneous absentee ballot application and absentee ballot, provided the FWAB reaches the appropriate election officials by the state absentee ballot application deadline. ${ }^{59}$

55 Of course, these other burdened voters could be first responders-fire fighters, Red Cross employees, etc.- dispatched to respond to an unfolding crisis.

56 See, e.g., 42 U.S.C. § 1973ff-6(1)(C) (Supp. IV 2011).

${ }^{57}$ UNIFORM MILITARY AND OVERSEAS VOTERS ACT § 2(9) (2010), available at http://www.uniformlaws.org/shared/docs/military\%20and\%20overseas\%20voters/umova_fi nal_10.pdf.

58 See Amended Substitute H.B. 224, 129th Gen. Assemb., sec. 1, § 3511.01(C) (Ohio 2012), available at http://www.legislature.state.oh.us/BillText129/129_HB_224_EN_ N.html.

${ }^{59}$ In Ohio, that deadline is noon on the Saturday before Election Day. See OHIO REV. CoDE ANN. §3511.02 (West Supp. 2012). Therefore, to take advantage of this accommodation a voter still might need to use it before knowing of an abrupt last-minute deployment. In that regard, early in-person voting through the Sunday and Monday before Election Day would still provide an additional option. 
Finally, as others have observed, the Obama for America equal protection claim was highly fact dependent, at least at the preliminary injunction stage. ${ }^{60}$ Its unique features include: the fact that Ohio was attempting to reduce the previously available period of early voting, giving rise to what some have termed a "non-retrogression" principle in equal protection analysis; ${ }^{61}$ defendants' evidentiary failure(s) to contest plaintiffs' asserted burden on nonmilitary voters, or to establish the burden on county election officials of offering early voting to all voters on the three days before Election Day; and the convoluted evolution of the statutory scheme, which could lead to the view that the defendants' claimed justifications were post-hoc efforts to rationalize an accidental enactment of an arbitrary advantage. In this factual context, the federal courts concluded that the defendants failed to establish a sufficient basis not to allow other voters also to take advantage of the same early in-person voting opportunities Ohio was providing to military voters.

\section{CONCLUSION}

Even if the precise conceptual theory by which the federal courts deem Ohio's early in-person voting process to violate the Equal Protection Clause remains in some ways under-theorized, the judicial desire to sustain typical military voting accommodations remains strong. It thus seems likely that, in whatever way the conceptual theory advances, it will continue to protect the viability of these valuable accommodations for military voters. Obama for America therefore will provide little precedential basis for undoing the range of significant improvements that Congress and state legislatures have developed for military (and overseas) voters over many decades.

\footnotetext{
60 See, e.g., Michael S. Kang, Michael Kang Responds to Foley on Obama for America Non-Retrogression Principle, ELECTION LAW @ MORITZ (Sept. 7, 2012), http://moritzlaw.osu.edu/electionlaw/comments/index.php?ID=9689.

61 See Richard L. Hasen, The 2012 Voting Wars, Judicial Backstops, and the Resurrection of Bush v. Gore 13 (U.C. Irvine Sch. of Law, Paper No. 2012-75), available at http://papers.ssrn.com/sol3/papers.cfm?abstract_id=2182857\#\#; Edward B. Foley, NonRetrogression, Equal Protection, and Ohio’s Early Voting Case, ELECTION LAW @ MORITZ (Sept. 6, 2012), http://moritzlaw.osu.edu/electionlaw/freefair/index.php?ID=9673.
} 